\title{
Combined effects of $y$-irradiation and ascorbic acid on the physicochemical properties, microbial stability and aroma profile of onion puree during storage
}

\begin{abstract}
The onion was first pureed and then added with $0.5 \%$ ascorbic acid before it was $\gamma$-irradiated at $2 \mathrm{kGy}$. The puree was then stored at 4,10 and $27 \mathrm{C}$ for up to 28 days. Changes monitored included $\mathrm{pH}$, titratable acidity, total soluble solids, color, total bacteria and yeast counts, organic acids and sensory property of the puree. Results show that the combined treatments reduced the contamination levels of the total bacteria and yeasts, and it helped to stabilize the color, and other physicochemical properties, such as $\mathrm{pH}$, acidity, organic acid composition and contents of cold-stored onion puree. This study has shown that onion puree kept the initial color of fresh onion puree after $2 \mathrm{kGy} \gamma$-irradiation if it contained $0.5 \%$ ascorbic acid and storage at $4 \mathrm{C}$ for 28 days.
\end{abstract}

Keyword: Combined effects; $\gamma$-irradiation; Ascorbic acid Physicochemical properties; Microbial stability; Aroma profile; Onion puree 